\title{
NAVIGATING THE CITY: RITUALS, ROUTINES AND RELATIONSHIPS IN THE MAKING OF DELHI'S ORDINARY STREETS
}

\author{
SAmprati Pani \\ Graphic designer and sociologist, Shiv Nadar University \\ https://dx.doi.org/10.12795/astragalo.2020.i27.09
}

\section{THE SMALLNESS OF BIG CITIES}

Cities are such massive, heterogeneous and excessive creatures that they might appear as impossible to study and understand. In particular, the South Asian city has been constructed as baffling and opaque, its sociality unpredictable and its 'ways and forms without codification', not only for anthropologists but also for its 'natives' (Gandhi and Hoek 2012: 3-5). Studies on Delhi also point to a similar challenge in analyzing the city, which has a fragmented, heterogeneous and discontinuous history, urban fabric and spaces (Vidal et al. 2000) and is characterized by 'extraordinary upheavals and changes' that are disorienting (Chaturvedi 2010: vii). Vidal et al. (2000: 15) argue that it is difficult to fix the complexity of Delhi into a single image: 'The reality of India's vast capital is at once more diverse, more anarchic and at times more intriguing than the semi-mythical Delhi of the tourist book imagination.'
Curiously, the same authors present a single image of Delhi when they point out that unlike Mumbai or Calcutta, Delhi does not evoke loyalty, affection or a sense of belongingness among its (largely migrant) dwellers:

$$
\begin{aligned}
& \text { The inhabitants of Delhi [...] are } \\
& \text { either indifferent or actively dis- } \\
& \text { like the city in which they live. } \\
& \text { With the exception of a few chasers } \\
& \text { of djinns, of the writer, Khushwant } \\
& \text { Singh, some descendants of long- } \\
& \text { established Delhi families and a } \\
& \text { smattering of others [...] hardly } \\
& \text { anyoneis ready to declare a passion } \\
& \text { for Delhi. (ibid.: 16) }
\end{aligned}
$$

In a similar vein, Sengupta (2007) advances that people who settle in Delhi do so for instrumental reasons-professional, educational or housing-rather than affection for an envi- 


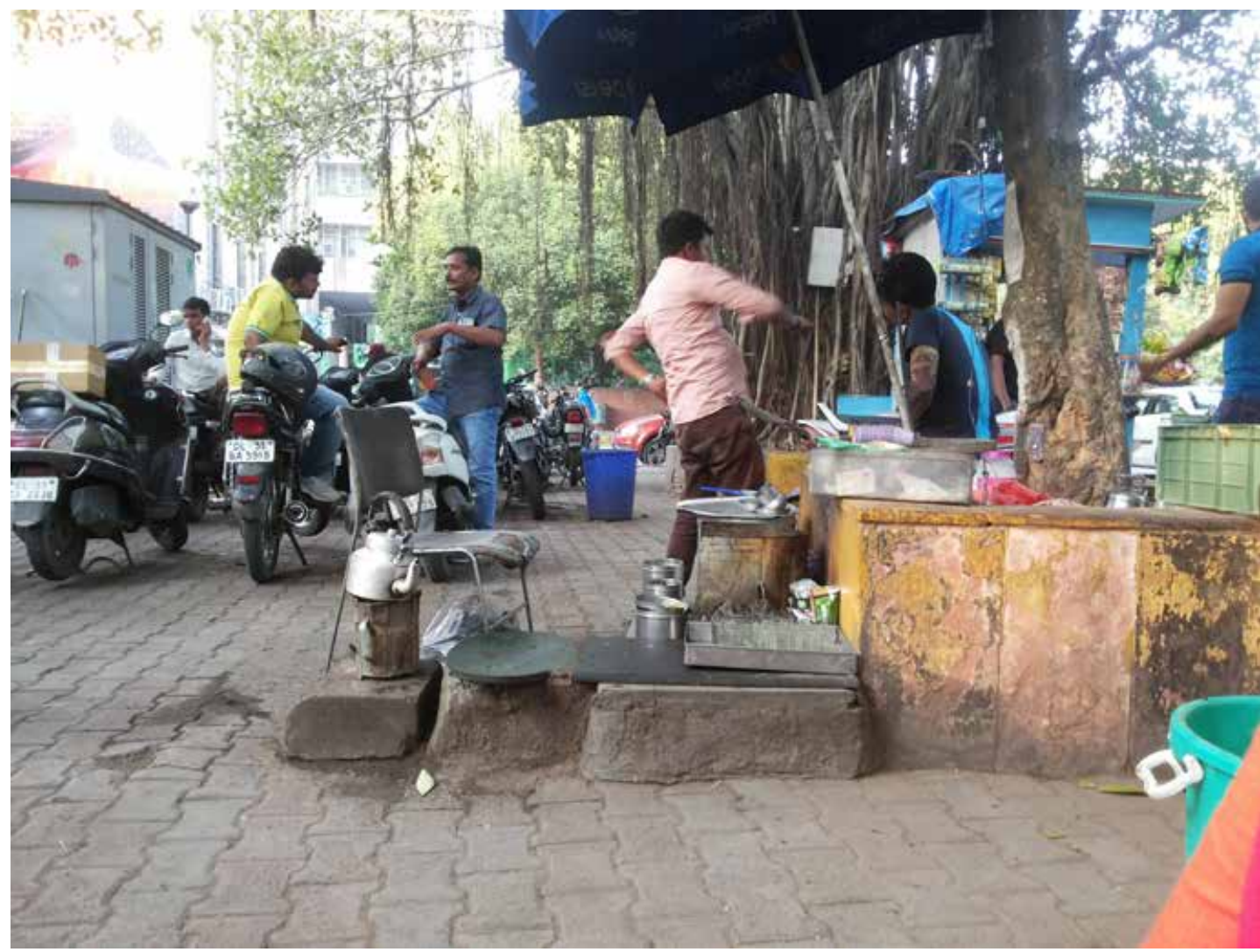

Image 1: A tree providing the material locus for a tea shop, which in turn is a 'meeting place' on a street behind Khan Market, south Delhi. Photograph by author.

ronment or a way of life. Moreover, she argues that the deep sense of attachment to the city expressed by long-term residents whose families have lived in Delhi over several generations is not to the city of the present but to a past glory that has been lost, 'their loyalties are to their Delhi, a vanished, magical world of unhurried grace and honest shopkeepers' (ibid.: 7).

It is precisely the size and diversity of cities that makes them amenable to various contradictory 'ways of seeing' and representations. Seeing not only 'establishes our place in the surrounding world' (Berger 2008 [1972]: 7) but also makes that world in its image. Drawing on Berger (ibid.) that the relationship between seeing and the world is never resolved but rather is a continuous process, I argue that the city is not an objective thing outside of us-it is continuously made through our relationship with it. So the same city can be simultaneously made as endearing yet alienating, cruel yet compassionate, abundant yet poor. This is what Raban (2008: 2) refers to as the 'plastic' nature of cities: 'We mould [cities] in our images: they, in turn, shape us by the resistance they offer 
when we try to impose our own personal form on them.'

I argue that one cannot see or experience the city in its entirety but rather through what Jane Jacobs (1958) refers to as the 'smallness of big cities'. ${ }^{1}$ We live our lives in the city through its smallness - of relationships, communities and places of our making. Whether Delhi's residents have a sense of loyalty or affection for the city or not, whether they comprehend it entirely or not, their everyday lives (and of the city) cannot continue without some sense of familiarity, comfort, attachment and/or affection to small places in the city-a room or a corner in your house, a pavement teashop or a hip cafe where you hang out with friends, a spot outside your office where you smoke with colleagues, a patch on the road where you ply your wares from, the weekly bazaar you frequent. ${ }^{2}$

This essay argues that one way of navigating the megacity of Delhi is through its smallness - its associative milieus of place making around particular streets, street bazaars, pavements and street shops. ${ }^{3}$ The pursuit

$\mathbf{1}$ Jacobs argues that what makes a city large is not large infrastructure projects or businesses or monumental architecture but the large number and proportion of small enterprises as well as 'a large collection of small elements, where people can see them, at street level' (1958). I use her phrase here to refer to the smallness of everyday lives in a big city like Delhi and the enormous number and diversity of such small lives, many of which are located in or spill over into the street.

2 Weekly bazaars are makeshift periodic markets set up on a fixed day of the week in different neighborhoods of Delhi.

3 See, for instance, Pani (2020) for an ethnography of place making in Delhi around the ordinary locus of the weekly bazaar, with a focus on routines and practices located in the streets of Nizamuddin Basti.

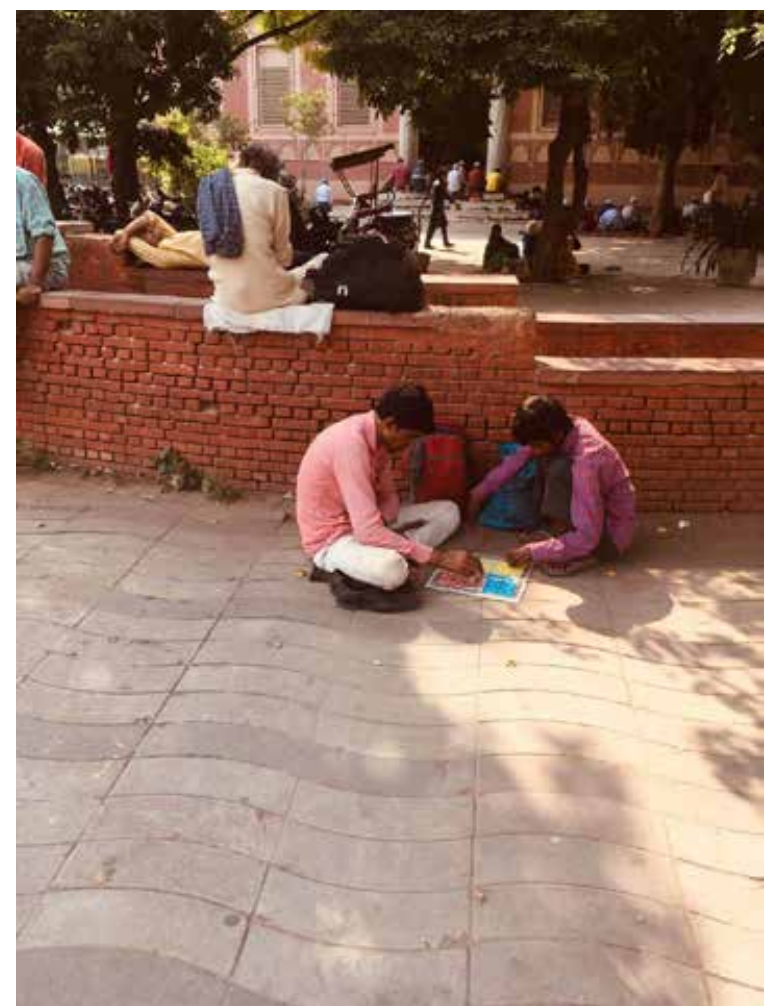

Image 2: A game of ludo in progress, Baba Kharak Singh Marg, central Delhi. There are a number of activities happening in the background - a man sleeping and others resting, men praying on the steps of a mosque, with some spilling over into the street, beggars sitting around and passersby walking. Photograph courtesy of Sarover Zaidi.

here is not to establish the essence of a 'South Asian city' or the 'culture of the Indian street', whether located in terms of difference from Western cities (Edensor 2006) or as a contested relationship with the project of modernity (Anjaria 2012). Nor is the aim to draw up a classificatory system of streets based on 'indigenous' architectural forms (Fonseca 1969, Soud 
and Haque 2018). ${ }^{4}$ Instead, the essay looks at the making of ordinary streets in Delhi-how do streets perform as public places-through a continuous flow of people, materials, objects, relationships and activities that has 'turned back on itself in a loop or fold' (Nail 2016). Such a processual approach to places provides a way to steer clear of the reified categories of South Asian and Western cities and opens the possibility of thinking of 'a world of ordinary cities, which are all dynamic and diverse, if conflicted arenas for social and economic life' (Robinson 2006: 1).

\section{THE ORDINARY STREET}

'In the Middle Ages, a road or way was merely a direction in which people rode or went, the name street being reserved for the made road' (Weekley n.d., emphasis original). What makes the street a made road is less asphalt and concrete than the layers, densities and textures of different uses and practices that its surfaces go through and accumulate.

The history of the making of cities has been traced through the building and rebuilding of its streets, whether it was Haussmann's restructuring of Paris in the 1860s through

4 Classificatory systems of street forms indigenous to Delhi, such as gali, kucha, katra and mohalla, have a historical specificity in the old city and are not useful to apply to the rest of Delhi (they have also not remained static within the old city). Moreover, a focus on form itself tells us little about how street architecture comes to be used and inhabited.

5 By Delhi, I refer to the National Capital Territory (NCT). The old city (Shahjahanabad), which is part of the NCT, has been the focus of a disproportionately large number of studies, historical and anthropological. For this reason, this ethnography consciously looks at streets in neighborhoods outside the old city.

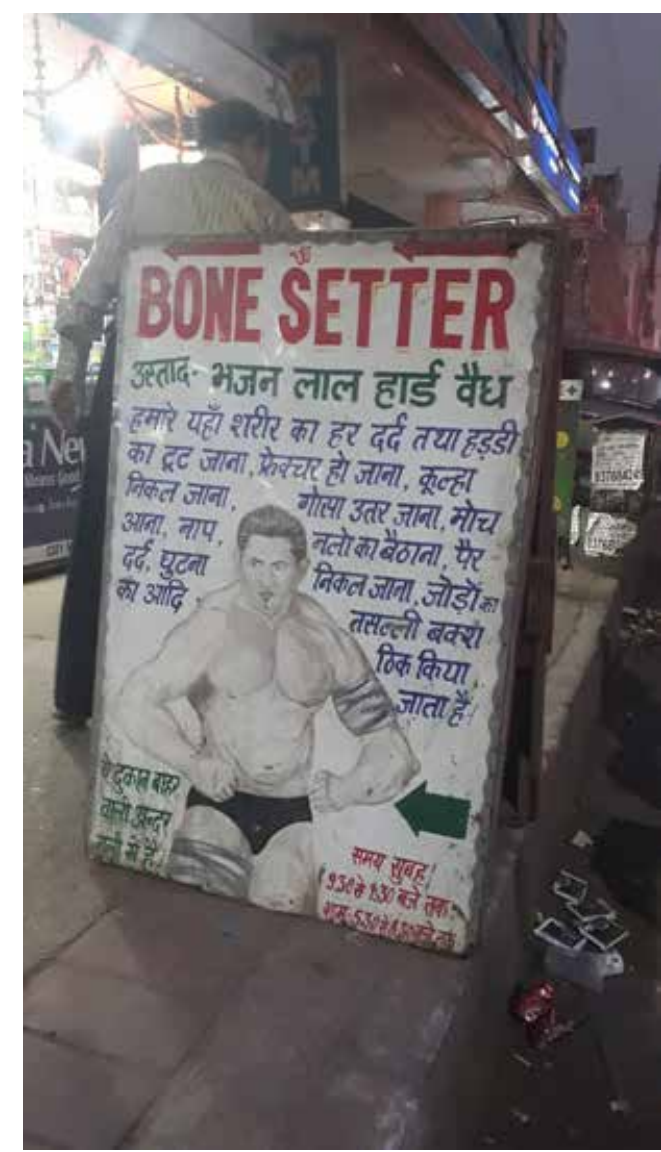

Image 3: Ambiguous forms of indexing a street also find their way into signage, which can only be 'read' by those familiar with the street's milieu. The bottom left of this signage for a 'bone setter' on a pavement in Shakarpur, east Delhi, reads 'yeh dukaan bahar wali andar gali mein hai' (this shop is on the outer-inner alley). Photograph by author.

long straight avenues that cut across crowded neighborhoods to manage traffic as well populations (Sennett 1970); the deliberate absence of street corners and squares in Brasília's modernist plan as a means of radical defamiliarization that would help obliterate class differences (Holston 1989); or the construction of a world-class aesthetics in millennial Delhi 


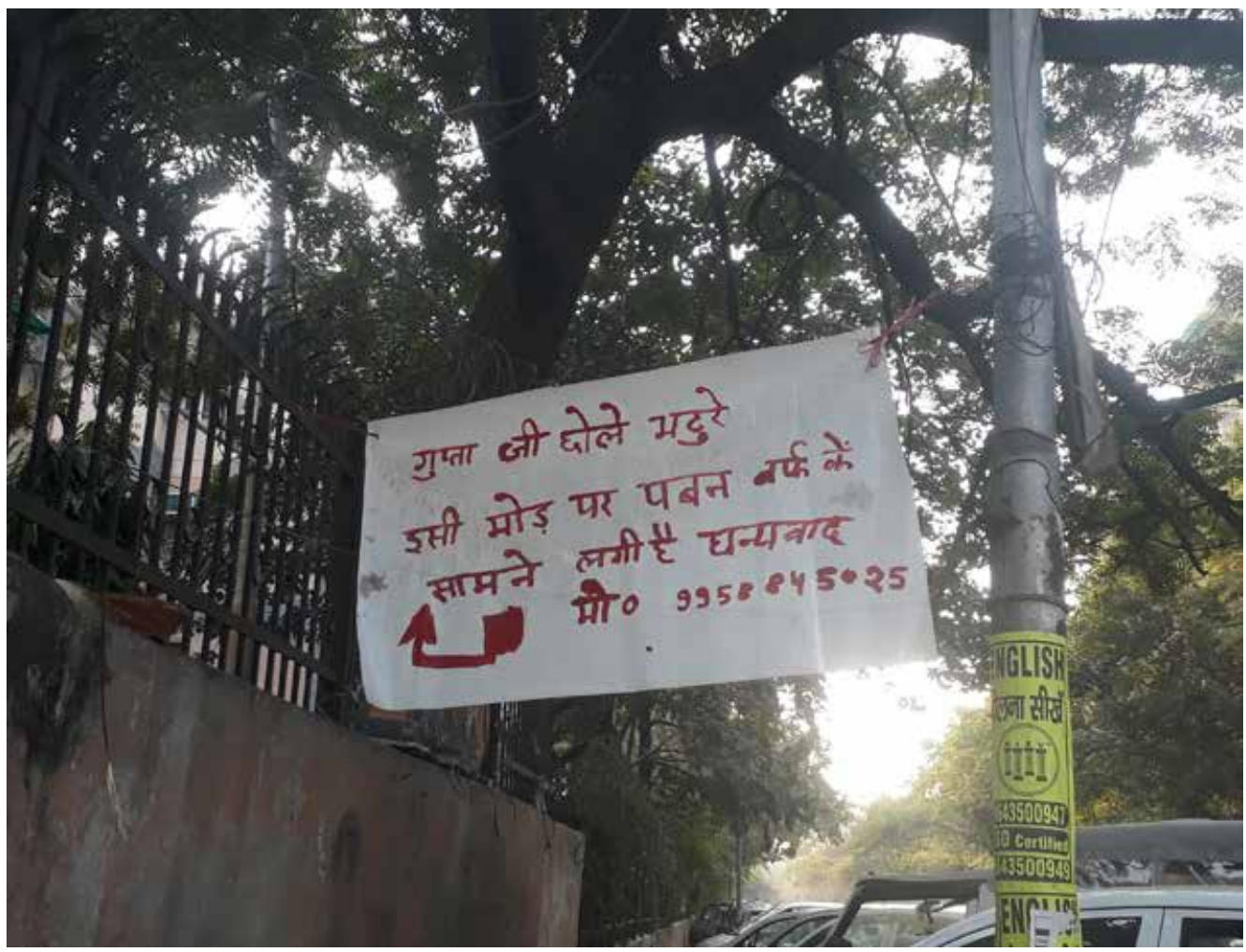

Image 4: Directions to a street food stall that has moved from its original spot for the benefit of its regular customers, Madhu Vihar, east Delhi. It reads: 'Guptaji chole bhature is around the corner in front of Paban Ice Shop. Thank you.' While the arrow is confusing, there is a reference to a permanent shop (a landmark) and a mobile number as well. Photograph by author.

to create a city that looks planned through the removal of people and activities that appear as informal (Ghertner 2015). Yet streets are far from being completely predetermined and disciplined by the vision of planners, architects and governments as encapsulated in master plans, policies and zoning laws.

Delhi, like many other cities, continues to have vibrant streets characterized by diverse activities, people, rhythms and movements. The alarmist and dystopian discourses around Delhi in terms of the death of public spaces, lack of infrastructure, unsafe streets and bad air quality have their value for corrective measures that need to be taken to make the city more liveable, accessible and democratic. But such discourses can sometimes make invisible the ways in which spaces in the city continue to function as public spaces or get transformed into public spaces through the ways in which people use and inhabit them. ${ }^{6}$

6 Gambetta and Bandyopadhyay (2012) argue that 'sounding the death knell for the public space of the street' 
The streets that form a part of this essay are ordinary. They are often bypassed in the popular trails of tourist and heritage itineraries, in the writing of histories and ethnographies, and in recommendations for culinary and shopping experiences in the city. They are non-descript, their surfaces uneven. They lie in between homes, offices, shops, schools, marketplaces, parks and neighborhoods, sometimes besides and in between the towering architecture of hi-rises, malls, business hubs, metro stations and restored monuments.

The ordinary street is cobbled together by the daily rhythms of bodies moving at different speeds and pausing for different intervals - the office goer running to catch the 9 am bus no. 534; gym friends having a cup of tea, and then another, from Shuklaji's tea stall, after a workout; the housewife taking a stroll through the Monday bazaar, looking but not buying; the college students hanging out and flirting at the corner momo shop in the evening. The ordinary street is indexed in ambiguous and eccentric ways by its different users, making sense only to them and others part of their personal milieu of the street. Bahar hoon, sadak pe, bazaar mein, chai ki dukaan par, hamari jagah pe, bus stop ke peeche, gate ke saamne, dhabe pe, kachde ki dher ke samne, Munna ke dukaan pe, konewalli juice ki dukaan par, naale ke parli taraf (outside, on the road, in the bazaar, at the teashop, at our spot, behind the bus stop, in front of the gate, at the roadside food stall, in front of the garbage dump, at Munna's shop, at the

ignores how public life transforms the meanings and uses that are associated with public space as well as how public space is itself utilized as a concept for bourgeois appropriations of urban space. corner juice shop, on the opposite side of the drain). These are the kind of responses that an ordinary person in Delhi is likely to give to the question 'Where are you?' or 'Where should I reach?' rather than the specific street (even one with a name) in a locality. The enactive potential of the street and its malleability derives precisely from this ambiguity-that it means different things to different people, as we will see in the three ethnographic vignettes presented next.

\section{RITUALS OF OUR MAKING}

A middle-aged businessman, living in Bhogal, a post-Partition rehabilitation colony, steps out of his house every morning to have breakfast on a street of his neighborhood. 'Main roz yahan pauhaunch jaata hoon-I land up here everyday', he tells me, on a chance encounter at Sardarji's thela (pushcart), which serves the day's dal and sabzi, raita and hari chutney, along with naan or paratha, freshly made and served hot, straight from the tandoor. I am intrigued why an Indian man living with his family, with the tacit privilege of being fed and served, would engage in this curious ritual and I ask him this. 'Main sochta hoon gharwallon ko kyun pareshan karoon, aur itna badhiya nashta ho jaata hai yahan' ('I think why should I trouble my family, and then the breakfast here is so good'), he says. The mischievous twinkle in the eyes and the broad grin, however, seem to suggest that it is more than just a matter of saving the family from the chore of breakfast. I watch him, the daily customer, as he chatters away in between the bites of food, which he is thoroughly enjoying. He encourages me to go for seconds, 'Bahut accha hai, le lo' ('It's very nice; go for it'). 


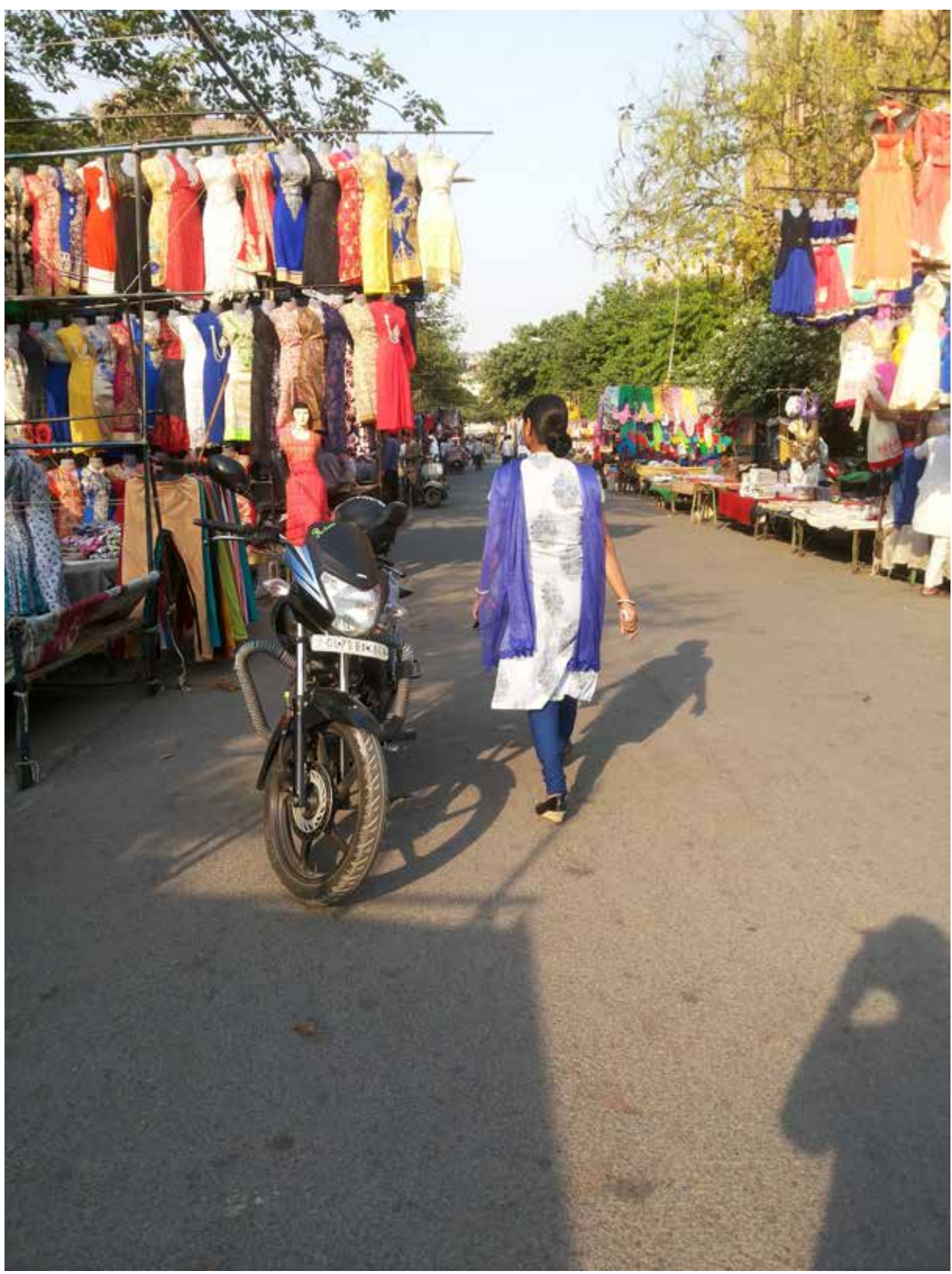

Image 5: Woman walking in the Monday Bazaar in Madhu Vihar, east Delhi, just before the evening crowds come in. Weekly bazaars are an iconic part of Delhi's street life. Photograph by author. 
Amrit Aunty, a 75-year-old woman, who lives in an apartment in IP Extension in east Delhi, is restless to go the bazaar. 'Bazaar', for her, is a generic term referring to the world outside her apartment complex. It could mean walking up to the Safal booth, or the kirana store in the dull, dilapidated Delhi Development Authority (DDA) shopping complex, or a rickshaw ride across the Mother Diary factory to the crowded streets of Pandav Nagar, or roaming through the weekly bazaar that pops up on the road right outside her apartment gate every Wednesday. It's not like she needs anything in particular from the 'bazaar' today. 'Subah se ghar pe baithi hoon, ajeeb sa lag raha hai' ('I am feeling weird sitting at home all day'), she tells me. Most days, she steps out with Anjali, the domestic help, in the evening-she purchases vegetables and groceries, whether required or not, for the house and for Anjali, and on the way back buys samosas for both of them and the rickshawwalla who drops them home. Today, Anjali did not turn up, and Aunty is fidgety and restless. She dismisses her son's suggestion of taking a walk around the apartment complex as inane and dull. Aunty insists on going to the 'bazaar', refusing to carry her mobile phone despite her son's insistence and even forgets her wallet at home. She returns from her excursion in good spirits. 'Bazaar ka chakkar lagake, ab thoda theek lag raha hai' ('Having done a round of the bazaar, I am feeling a little better now'), she says.

Rani, a resident of Nizamuddin Basti, a lowincome locality in Delhi, is a mother of three grown-up children and is part of a women's self-help group for which she makes crochet products. Every Monday, she wraps up her household chores earlier than usual so that she can leave for the weekly bazaar, which takes place in the alleys of the Basti. She reaches her place of work much later on Mondays than other days. Her commitment to this routine is unfailing-in her own words 'Main Monday ke Monday jaati zaroor hoon' ('I go every Monday for sure') - despite her husband's admonishments about what the need is to go every week and his instructions to not spend too much time in the bazaar. The odd Monday she cannot go to the bazaar for some reason, Rani loves looking at it from her terrace, which provides an excellent view, struggling with the temptation to go down, and sometimes giving in to it. Many other women from the Basti also engage in the ritual of going to the bazaar every Monday. Not only do different women do different things in the bazaar but also every visit is unexpectedyou bump into friends and relatives you have not seen in a while, you discover new vendors, new deals, new things, some of which are available only on that day, which is why it is imperative for these women that they go every week.

What is so alluring about the street that compels the creation of routines around it, which are fervently maintained? Is it the commodities that the street has to offer, that we cannot imagine modes of respite from consuming lives without consuming things? But then, why do office-goers linger, loiter, and drag their feet in the lanes, backstreets, and pavements around their workplaces after the customary smoke, ice cream, or paan has been consumed at lunchtime? What dis- 
tractions, marvels and amusements does the street offer? Or are the things incidental, serving as easy legitimate excuses, and the rituals of our own making?

The rituals described in the above ethnographic vignettes are not the Durkheimian rituals that hold society together or represent the abstract idea of society to individuals. Nor are they Goffman's codes of everyday behavior through which individuals collaborate in creating a shared reality and uphold each other's sense of self. Here, each ritual is a habit that has grace (allowing for ease, facility, power to resist) and is a resource of possibilities rather than being mere mechanical repetition ( $\mathrm{Ra}$ vaisson 2008). These habits have no compelling instrumental reasons, and yet, they are often spoken of in terms that are obligatory: 'Mujhe shaam ko chai ki tapri pe jaana hi jaana hota hai' ('I have to go to the tea stall every evening') or 'Main har Somwar, bazaar ka ek chakkar zaroor lagata hoon' ('I make sure I do a round of the bazaar every Monday'). This curious mix of habit, desire and compulsion of being out on the street is what I refer to as rituals of our making.

A recurrent response I have received from mostly upper middle class and middle class residents of Delhi while discussing my research on practices of walking, loitering and roaming in streets and bazaars is of sheer disbelief. They tell me that Delhi is not a walkable city, besides being unsafe and polluted, so no one walks in the city, let alone loiter, unless 'they' (usually a reference to the urban poor) have absolutely no choice. At a public event, ${ }^{7}$ where I was presenting my work on walking in bazaars, an audience member very categorically told me that no one spends time on the streets of Delhi and that even when the 'poor' go to the bazaar (the rich can avoid such dangerous activities), they shop quickly and head back. Another audience member was willing to concede that there might be some loony characters that roamed the streets of Delhi, loony because, she explained, they were exposing themselves to sexual assault (if they were women) and health risks on account of the pollution. The city of nightmare is not less real than the city that inhabits the street or longs to be in the street. It is not just a domain of discursive regimes but is linked to spatial practices involving exclusion, segregation, avoidance and repugnance.

The street has to be necessarily traversed for getting from here to there in the city, for work, leisure, chores and appointments. A large segment of the throng of bodies (and traffic) moving on the street is out on the street to get away from the street. But there's no escaping the street, without passing through it. And the street with its nameless passersby and nameless other users, as well as density of activities, allows for more people to want to be on the street because they too can be nameless. So that they can-perhaps like the businessman in Bhogal, the elderly woman in IP Extension and Rani in Nizamuddin Basti-escape routines, through the creation of other routines. Be here, yet elsewhere, create time that does not have to be accounted for, invent diversions that are private.

7 'Of calibrations and conversations, or how to measure time in walking', Sarai-CSDS, Delhi, 18 February 2019. 
The very public character of the street allows for private or 'other' or 'real' selves to emerge, being part of the crowd allows the person on the street to drop out of society and be, or strive to be, an individual. The old woman from a middle-class family in Jangpura who eats rajma chawal from the pavement at least once in a week, not because it is particularly tasty, but so that she can sometimes break the monotony of eating the bland, healthy food she has to cook for her health-conscious son. The teenage lovers in Nizamuddin Basti for whom walking in the teeming bazaar is the only opportunity for their bodies to brush against each other. The woman who, in the name of buying provisions, not only gets to wander the streets of Bhogal alone but also saves a tiny part of the shopping money for herself. These tiny respites, resistances, possibilities of freedom do not dis- rupt the tight circle of everyday routines and codes but make tiny breaks in them, making for what Raymond Williams (1977: 132-33) refers to as 'social experiences in solution', emergent forms of practices and experiences that defy definition and classification.

Drawing an analogy between linguistic and pedestrian enunciation, de Certeau (1988: 99) points that 'this location (here-there) (necessarily implied by walking and indicative of a present appropriation of space by an "I") also has the function of introducing an other in relation to this " $\mathrm{I}$ " and of thus establishing a conjunctive and disjunctive articulation of places'. One can argue that walking, roaming or being out in the streets allows and establishes a conjunctive and disjunctive articulation of selves-selves different from or in addition

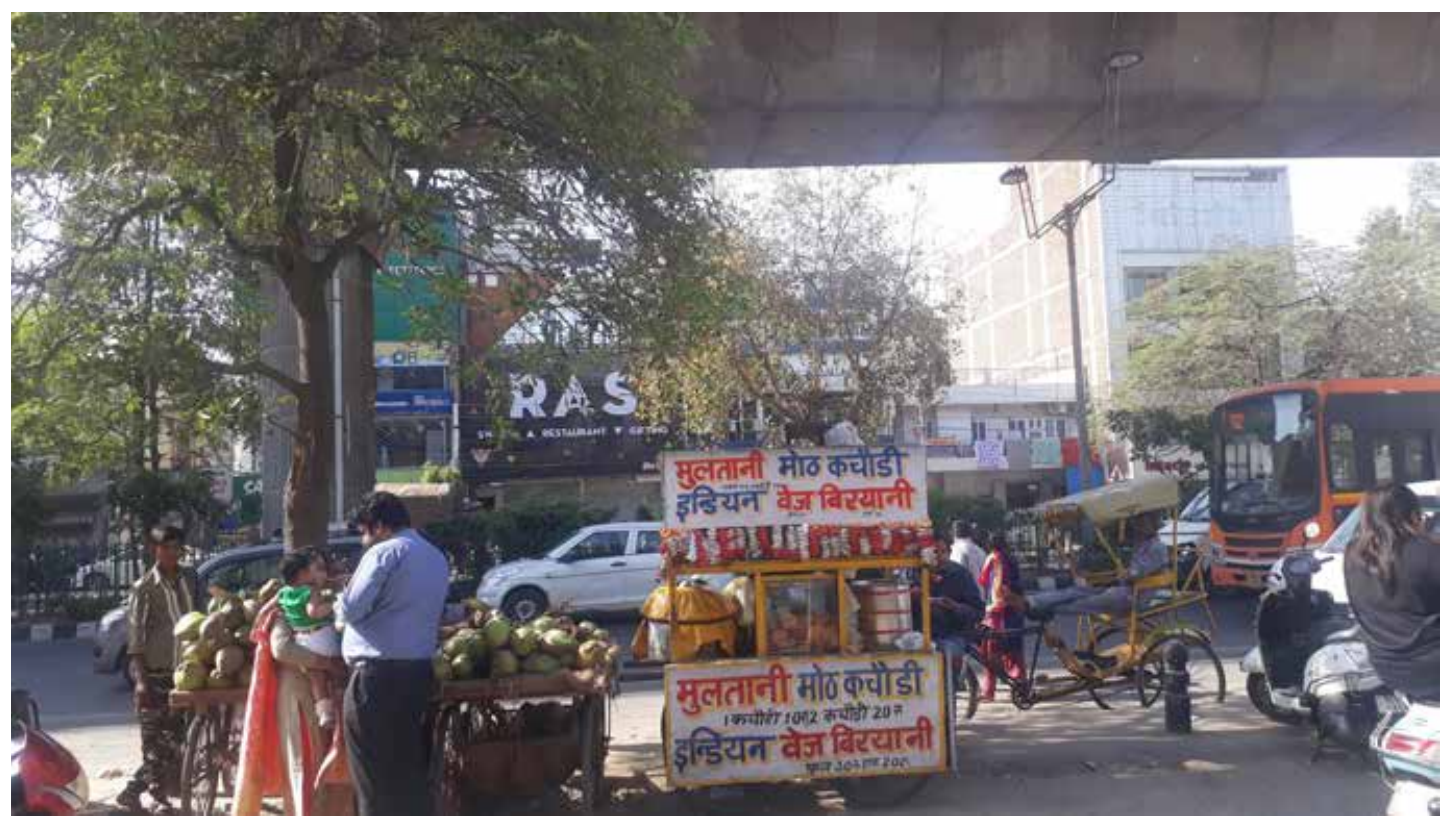

Image 6: Street around the Preet Vihar metro station, east Delhi. Spaces under and around metro stations in Delhi are buzzing intersections, usually revolving around street food. Photograph by author. 


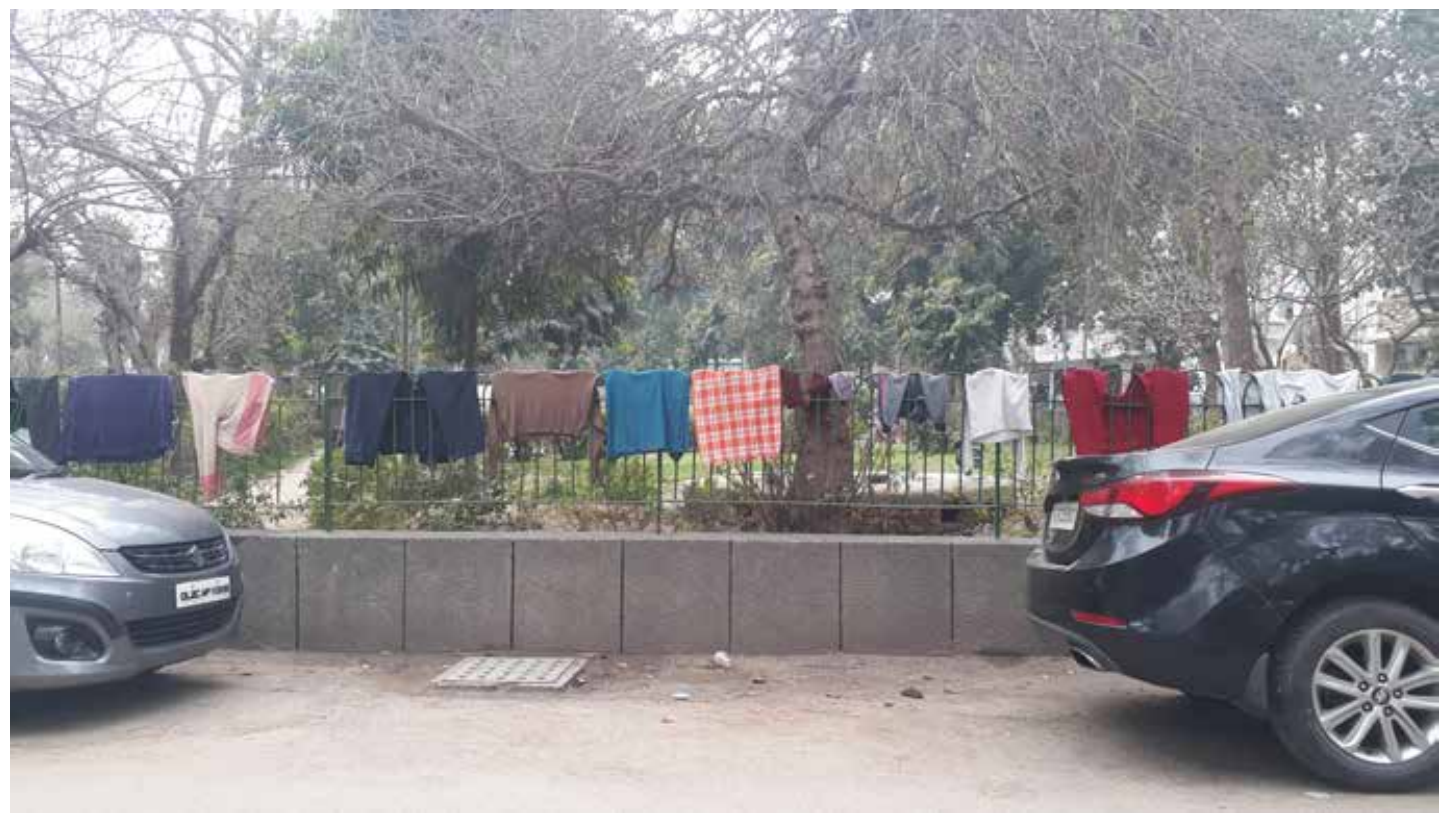

Image 7: Malleable street surfaces_railing of a public park in Bhogal, south Delhi, used by residents to dry laundry. Photograph by author.

to those not possible in confined places such as homes or offices or within the roles expected of selves in these spaces. Even as their itineraries and desires (and fears) might be very different, and often remain private, those escaping the street and those escaping into the street together make the street as a place, animating its 'structures of feeling' and setting its rhythm into motion.

\section{THE SHAPE-SHIFTING STREET}

The density and diversity of routines that make the street a place would not be possible without a material locus, which enables the intersection of relationships, movements and communications. It is this intersection that makes the street a constellation of 'meeting places' (Massey 1994: 154), giving it specificity, yet making it amenable to different imaginations and uses, to conflicts and negotiations, and making it more than just a paved road. A bazaar is among the more evident 'meeting places' that draws in people, commodities, services, enterprises and infrastructures. But the 'meeting place' could also be a tiny intersection of lines of movement on the street-a bus stop, the shade under a tree, a pavement, a concrete slab, a street corner, a traffic light, a T-point, a shop front or the space outside a metro station. Such an intersection, with the enormous flows of people through it, draws into its fold various kinds of street vendors selling a wide range of wares such as mobile chargers and earphones, balloons and plastic toys, meals and snacks, tea, juice, water, paan and cigarettes, vegetables and fruits, and a wide range of mending and other services such as shoe, bag, zip and umbrella 


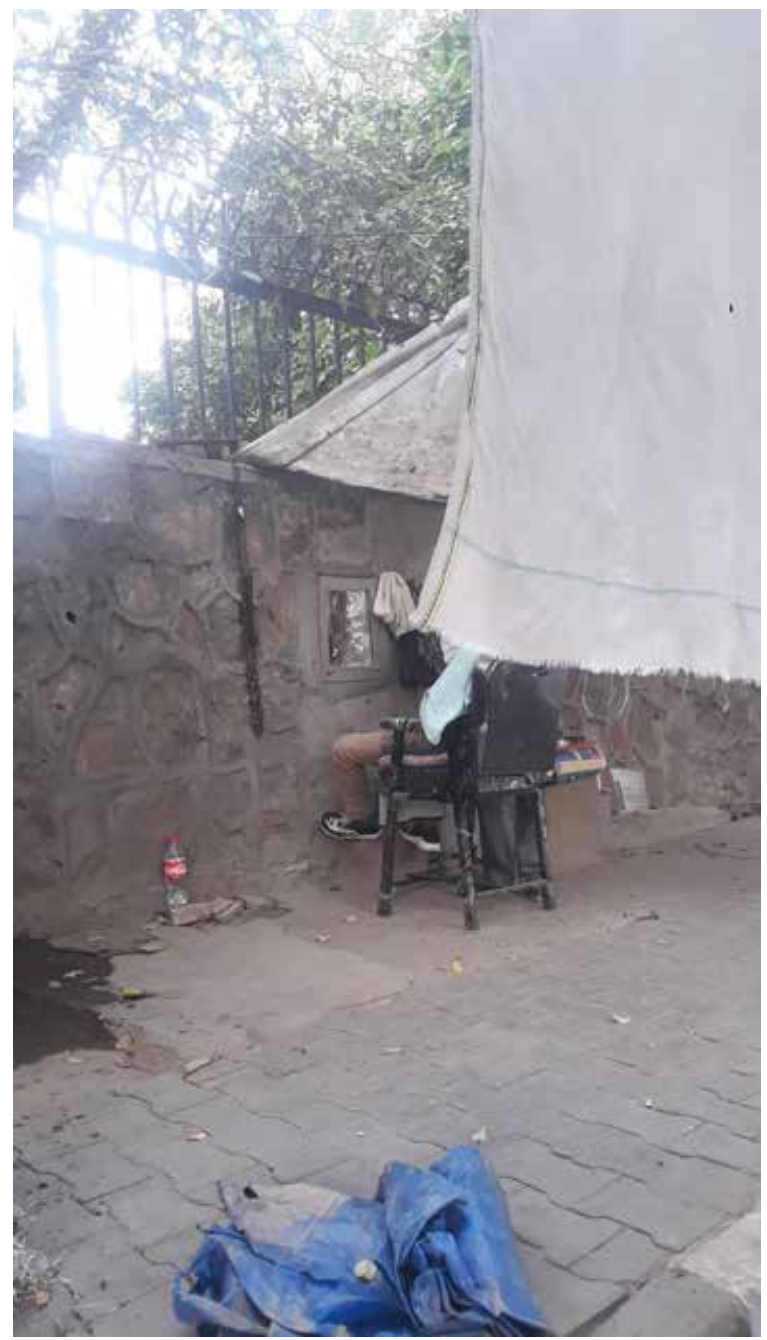

Image 8: Makeshift barber shop on a pavement in Ber Sarai, south Delhi. The barber has fixed a mirror on the wall to mark his spot on the street. The plastering around the mirror makes it blend into the materiality of the wall. Photograph by author.

repair, tailoring, key making, cycle repair, earcleaning and miracle cures.

The presence of such vendors draws more people to these intersections to not only buy provisions, grab a bite or get something fixed but also rest, relax, hang out, meet up with friends, lovers or colleagues, adding densities of sociality to these points of intersection on the street. People often plan their itineraries around the routines of particular vendors (e.g., a vendor who sells fresh fruits in the morning or a chaatwalla who sets up his thela at a fixed spot in the evening). Vendors too, in turn, often time their plying hours according to the routines of specific categories of people (e.g., a chaiwalla catering to early morning walkers and newspaper deliverymen, a rollwalla catering to the hungry evening office crowd). The rhythms, needs and desires of the city coalesce at, and continuously make, such 'meeting places'.

It is difficult to delineate whether the malleability of the street is derived from its different users or whether the surfaces themselves are malleable to different uses. An innocuous road divider that I pass by regularly when I step out of my apartment block becomes different things at different times of the day and for different users - a place for daily wagers to sit with their tools early morning, a spot for a barber to set his shop later in the day, its railing a place for a dhobi to dry out clothes, its concrete ends dropping points for vendors to deposit vegetable waste for cows and for residents of the nearby apartments to leave food and water for street dogs and birds. Here, the road divider is clearly exceeding its intended function of managing traffic and is being moulded by its different users, but the materiality of the divider also shapes and limits the extent of the uses it can be moulded into (for instance, it does not transform into a weekly bazaar). 


\section{FIELD OF CODES}

While the practices and materiality of ordinary streets in Delhi might be relatively flexible, these streets are not without codes. Apart from zoning laws, traffic rules and other spatio-legal codes that regulate streets, there are also various informal codes that regulate life on the street (e.g., not setting up a thela at a spot which is already taken). Like any code, the codes that regulate streets are continuously negotiated and improvised, but the street is not a tabula rasa with infinite possibilities of making, as we will see from the following two ethnographic accounts.

Babluji sold tea, paan and cigarettes from a cycle in a DDA market in a posh neighborhood in south Delhi. He worked from $7 \mathrm{pm}$ to $4 \mathrm{am}$, catering to the evening crowd and in particular the late-night customers-people catching the late night film show and people heading back from an adjoining nightclub. Babluji was amiable and always impeccably dressed. Many young people frequenting his shop would chat up with him and hang around his shop. When I interviewed him, ${ }^{8}$ he had been working on the street for less than a year. Hailing from a village in West Bengal, he had worked as a cook in Delhi for over 20 years. His last job as a cook was in a kothi (bungalow) across the market, where he worked for many years. He was fired from that job, an incident that made him realize he no longer wanted to work for anyone. He wanted to start a food stall in the market, but the existing food vendors were unwilling to make space for him or allow him to find a space for himself. After trying to persua- de them for a couple of months, he decided to make a shop of his cycle. The existing paan and cigarette shops, however, did not allow him to park his cycle shop close to their shops, regarding him as competition. Finally, he settled for a spot close to the parking lot, which faces some restaurants, a beauty saloon and a gym. He had to persuade each of these businesses to let him be, negotiating over five-six months.

The cycle allowed him to be mobile within the market and its surroundings. Even if it meant that he did not have a lucrative spot of his choice, he could move around to escape harassment (from existing vendors, guards of shopping outlets and the local police) as well as move to different spots in the market that drew customers through the night. He claimed he did not have to pay off the police because he did not have a permanent spot. Despite the perks of his mobile shop, he dreamed of having a 'permanent' food stall in the market (he was proud of his culinary skills and experience as a cook). 'It will take time but I will find a way', he told me the last time I met him. He disappeared a few months later, and on asking some vendors in the market, I was told that he had left and they did not know where. The nightclub had shut down, following a Supreme Court ruling on 1 April 2017 that banned the sale of liquor within 500 meters of state and national highways (the club was adjacent to a highway). This drastically shrunk his customer base and made it difficult for him to continue to ply from that market.

8 Over the months of January-March 2017. 
Guptaji, as people referred to him, ran a fastfood thela in the evenings, selling chow mein, chilli potatoes, burgers and other snacks, which were reasonably priced and catered primarily to a low-income clientele. He had been operating from a spot on a pavement outside an apartment block in east Delhi for 15 years at the time that I met him in mid-2016. He lived close by in Madhu Vihar with his brother, sister and mother, all of whom helped him run his thela. He was doing well and was happy that he was his own boss and did not have to do naukri (wage labour) for anyone. Sometime towards the end of 2016, Guptaji added a new item to his menu-pizza (or 'pijja' as he called it). He had a gotten a separate banner made for his pizza menu, which was tied to the front of the thela. The pizzas were an instant hit with his customers and also attracted a new clientele, residents from the nearby apartments. Priced at Rs 100-150, with generous toppings of a branded cheese and fresh vegetables, they were affordable and a novelty for his loyal customer base and a steal for the apartment people. He would make the pizzas himself, not letting his sister or brother try their hand at it, and would do it with a lot of care, often customizing it to the requirements of his customers. He would even do limited home deliveries to the apartments close by. His pizza was a staple for me on days I returned late from fieldwork and had no energy to cook dinner. He would love repeating to me on such occasions how pizza outlets are actually ripping off customers and are miserly with their toppings, while he is managing to do well without compromising on the ingredients. About six months into introducing the new item, Guptaji stopped serving pizza regularly and even removed the pizza menu from his thela. When I asked him about it one evening, he said, 'Jab tak burger, chow mein bech raha tha theek tha. Pizza itna chal gaya ki main ab nazar mein a gaya hoon. Policewalle ab zyada paise mang rahe hain' ('Till I was selling burger and chow mein, it was fine. The pizza did so well that I have come under scrutiny. The policemen are demanding more money now'). While Guptaji himself would be often be cryptic about this 'scrutiny'-he would sometimes say, 'Woh chalne nahin denge' ('They will not allow it')there were rumors abound in the street that the multinational pizza chain that had an outlet in a parallel street was putting pressure on him through the local police. At some point, Guptaji stopped serving pizza entirely, telling me that it was not financially viable for him to pay the hiked protection fee that the policemen were demanding. He was also thinking of moving from here to avoid harassment and had found a spot in Indirapuram (in Ghaziabad), 'Mera yahan guzara mushkil hote ja raha hai' ('I am finding it difficult to survive here'). He left a couple of months later.

Babluji partly abided by the code of respecting those on the street before him and partly subverted it by plying as a mobile vendor and creating a new customer base for himself (the night-time clients). He was managing to dodge the code of paying monthly protection money to the police in the short run, but he knew too well that his dream of having a permanent place in the market would mean he would eventually have to fall in line and pay a lump sum to police to be allowed to do so. The closing of the 
nightclub made it impossible for him to continue even as a mobile vendor, let alone save for his permanent stall in that market.

Despite following the code of being in the good books of the local police (many of whom ate at his stall) and paying the protection fee for 15 years, as well as having the benefit of a fixed spot, Guptaji was forced to start his life on the street elsewhere. He had violated a key code of the street-of being too big for his shoes, of having the audacity to introduce an item that is served in cafes and restaurants, of being unwilling to give in to the demands for the hiked protection fee. Removing pizza from the menu, however, did not restore his position on the street, with the police harassment continuing and resulting in his leaving 'his' place on the street.

How street codes play out is not always predictable, but that does not make them inconsequential in the making and remaking of streets and their everyday lives. These codes also connect the street to larger structures of power and inequalities in the city, making the street precarious and fraught with the possibility of disruptions.

\section{CONCLUSION}

The dynamism and vitality of ordinary streets in Delhi is not an intrinsic characteristic but rather is enacted through diverse small activities and routines. This continuous enactment makes the street a shape-shifting creature that transforms itself through different times in the day, week and year, through the different uses it is put to and through the different people that are drawn to it out of compulsion, affection or other reasons. It is this that makes the street a 'multiplicity', which is 'defined not by the elements that compose it in extension [...] but by the lines and dimensions it encompasses in "intension"' (Deleuze and Guattari 2013 [1988]: 286), what I refer to as the fold of the street. This is why, sometimes, the removal of any one intersection of lines from the fold of the street-a teashop or even a tree-can transform the affect of the street and, in some cases, even turn it into dead space. This is the reason why street vendors and weekly bazaars resist attempts by local authorities to relocate them at alternative sites because the unique folding in of actors, materials and rhythms they are part of cannot be easily replicated elsewhere.

The idea and value of the street cannot be traced to its essence but through how people work in and inhabit the street in time, how they join up with the street to create meanings, relationships, routines and the street itself. It is these practices that make concrete the idea of a street. When people speak of a street or a weekly bazaar or a chai shop as being unique, special, as having raunak (effervescence), as where they want to be, again and again, when a vendor starts and ends his day selling vegetables on a thela by praying to the patch of road where his thela stands, all these people are making their street, their meeting places, their city. 


\section{REFERENCES}

Anjaria, Jonathan Shapiro. 2012. 'Is There a Culture of the Indian Street', Seminar, issue on Streetscapes: A Symposium on the Future of the Street, 636 (August). Available at https://www.india-seminar. com/2012/636/636_jonathan_s_anjaria. htm, accessed on 12 August 2019.

Berger, John. 2008 [1972]. Ways of Seeing.

London: British Broadcasting Corporation and Penguin Books.

Chaturvedi, Bharati (ed.). 2010. Finding Delhi: Loss and Renewal in the Megacity. New Delhi: Penguin/Viking.

de Certeau, Michel. 1988. 'Walking in the City', in The Practice of Everyday Life, pp. 91-110. Trans. Steven Rendall. Berkeley, Los Angeles \& London: University of California Press

Deleuze, Gilles and Félix Guattari. 2013 [1988].

A Thousand Plateaus: Capitalism and Schizophrenia. Trans. Brian Massumi. London and New York: Bloomsbury Academic.

Edensor, Tim. 1998. 'The Culture of the Indian Street', in Nicholas R. Fyfe (ed.), Images of the Street, pp. 201-16. London and New York: Routledge.

Fonseca, R. 1969. 'The Walled City of Old Delhi', in P. Oliver (ed.), Shelter and Society, pp. 103-15. London, UK: Barrie \& Rockliff.

Gambetta, Curt and Ritajyoti Bandyopadhyay. 2012. 'The Problem', Seminar, issue on Streetscapes: A Symposium on the

Future of the Street, 636 (August). Available at https://www.india-seminar. com/2012/636/636_the_problem.htm, accessed on 12 August 2019.

Gandhi, Ajay and Lotte Hoek. 2012. 'Introduction to Crowds and Conviviality: Ethnographies of the South Asian City', Ethnography, 13 (1): 3-11.

Ghertner, D. Asher. (2015). Rule By Aesthetics: World-Class City Making in Delhi. New York: Oxford University Press.

Holston, James. 1989. The Modernist City: An Anthropological Critique of Brasília. Chicago and London: University of Chicago Press.

Jacobs, Jane. 1958. 'Downtown is for People', Fortune. Available at https://fortune. com/2011/09/18/downtown-is-forpeople-fortune-classic-1958/, accessed on 18 August 2019.

Massey, Doreen. 1994. Space, Place, and Gender. Minneapolis: University of Minnesota Press.

Nail, Thomas. 2016. Theory of the Border. New York: Oxford University Press.

Pani, Samprati. 2020. 'Of Basti and Bazaar: Women's Lives and Place-Making in Nizamuddin Basti, Delhi', in Hilal Alkan and Nazan Maksudyan (eds), Urban Neighbourhood Formations: Boundaries, Narrations and Intimacies, pp. 52-71. London and New York: Routledge.

Raban, Jonathan. 2008. Soft City. London: Picador. Ravaisson, Félix. 2008. Of Habit. London and New York: Continuum International Publishing Group. 
Sengupta, Ranjana. 2007. Delhi Metropolitan: The Making of an Unlikely City. New Delhi: Penguin.

Sennett, Richard. 1970. The Uses of Disorder: Personal Identity and City Life. New York: Alfred A. Knopf.

Soud, Sheikh Itmam and Md. Obidul Haque. 2018. 'Unearthing the Spatial Archetypes of Two Indigenous South Asian Cities: The Walled City of Old Delhi and Old Dhaka', in Y. Mahgoub, N. Cavalagli, A. Versaci, H. Bougdah and M. Serra-Permanyer (eds), Cities' Identity through Architecture and Arts, ebook. London: Taylor and Francis.
Vidal, Denis, Emma Tarlo and Veronique Dupont. 2000. 'The Alchemy of an Unloved City', in Veronique Dupont, Emma Tarlo and Denis Vidal (eds), Delhi: Urban Space and Human Destinies, pp. 15-25. New Delhi: Manohar.

Weekley, Ernest. n.d. Entry on 'street'. Available at https://www.etymonline.com/word/ street, accessed on 3 May 2020.

Williams, Raymond. 1977. Marxism and Literature. Oxford \& New York: Oxford University Press.

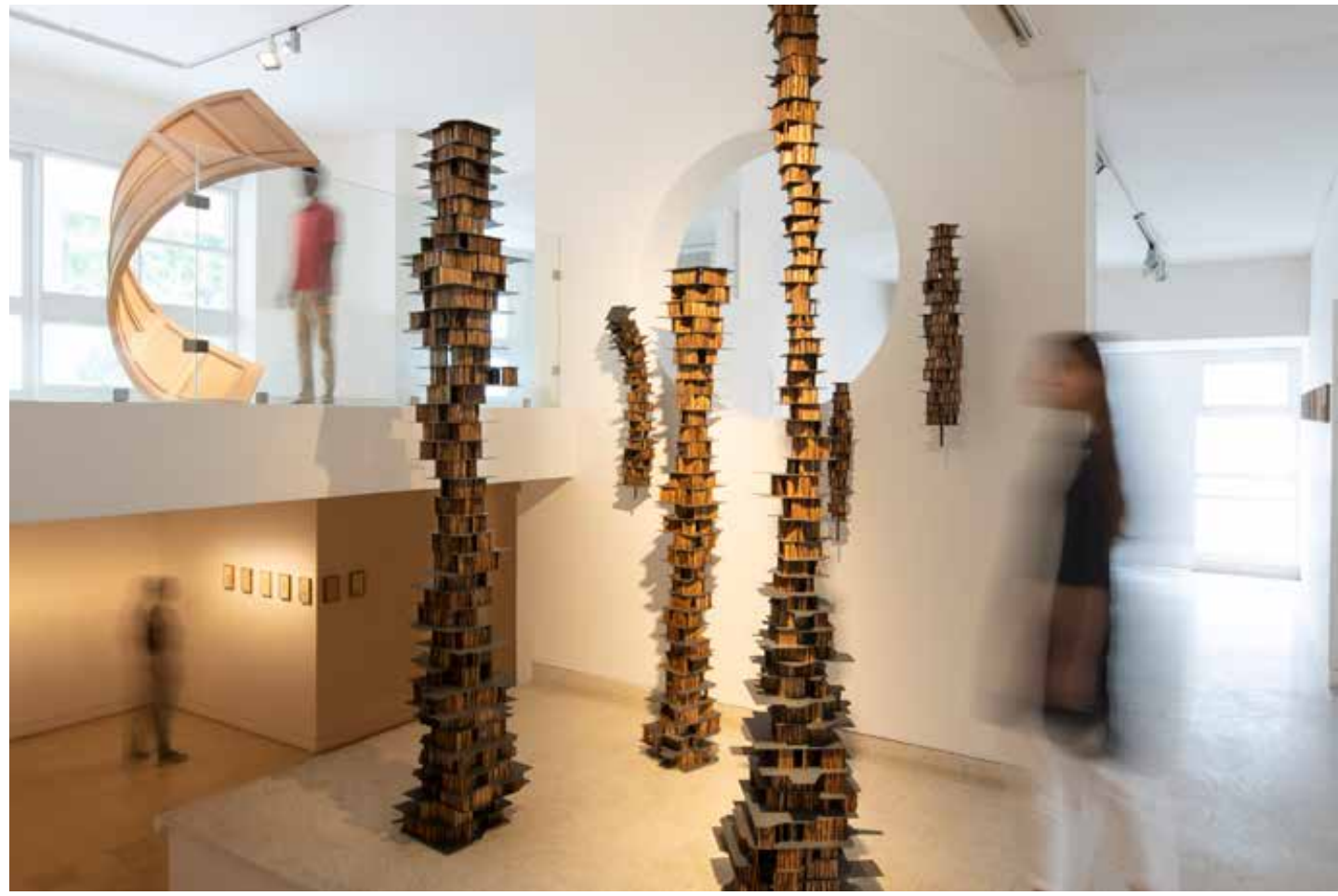



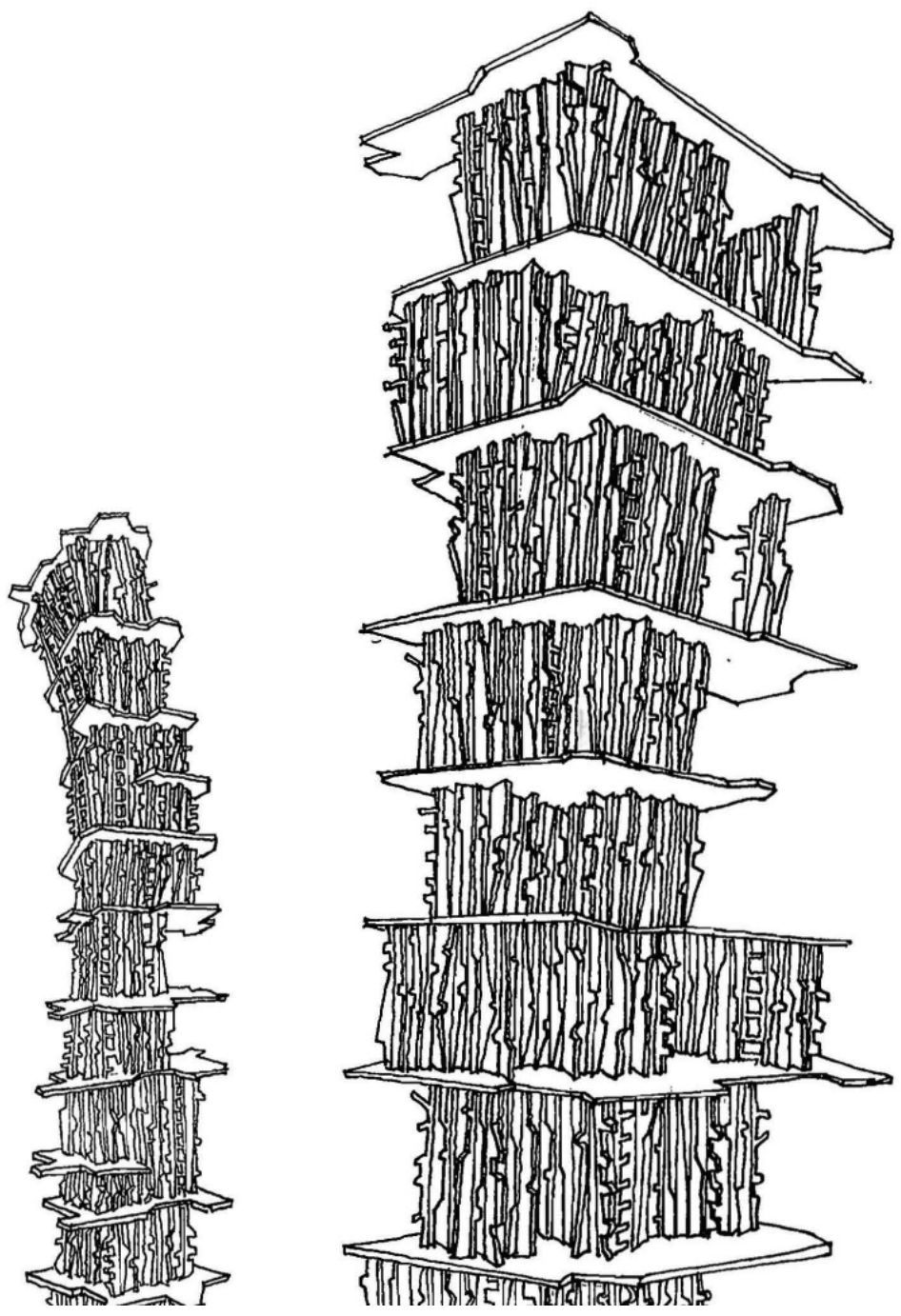

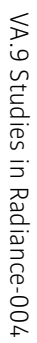

